\title{
Conclusions
}

The present survey shows that in spite of the slowness of chemical weathering and soil formation in Arctic climates, detectable quantities of cold extractable metals do accumulate in the regolith. Pulverised samples of any solid can be used and acceptable results can also be obtained on snow and water. Zinc is normally more important than the other metals accounted for both because of its mobility in surface waters and its strong reactivity with the colorimetric dye used in the geochemical method.

Although the present tests were carried out as a supplement to other field work and lack of time restricted a more thorough sampling programme the results show clear.correlations with known sulphide outcrops. Thus the method can be a useful tool in prospecting in Greenland.

\section{Reconnaissance mapping of the northern Blosseville Kyst between Kap Brewster and Kap Dalton, central East Greenland}

\author{
W. S. Watt, N. J. Soper and M. Watt
}

The northern part of the Blosseville Kyst between Kap Brewster and Kap Dalton was briefly investigated during a three week boat supported reconnaissance following an aerial interpretation of the coastal structure (Watt, 1975).

Most emphasis was laid on sorting out the relationship between the sediments at Kap Dalton and the structural relationship between the underlying and surrounding lava flows. Samples were collected for micropalaeontological studies both from the Kap Dalton sedimentary series and from a number of interbasaltic sediments (Soper \& Costa, this report). In addition a series of traverses were made through parts of the basalt succession between Kap Dalton and Steward $\emptyset$.

\section{Kap Dalton}

Wager's general interpretation of the structural setting of the Kap Dalton sediments on a down-faulted block was essentially confirmed (Wager, 1935). The block is about $5 \mathrm{~km}$ in width (fig. 40) and bounded on both flanks by major faults accompanied by crush zones up to $500 \mathrm{~m}$ in width with carbonate mineralisation along the fault planes. Along the edges of the down-faulted block the lava flows are steeply inclined $\left(\right.$ c. $\left.20-40^{\circ}\right)$ inwards against the fault plane. The down-faulted block was cut by a number of small faults after the deposition of the sediments and probably prior to the major faulting.

Soper \& Costa (this report) present palynological evidence for the age of the highest interbasaltic sediments within the down-faulted block and the age of the overlying sediments. 


\section{Structure of the area north of Kap Dalton}

North-east of Kap Dalton a broad zone of faulting trends parallel to the coast separating an outer zone of steeply dipping basalts from an inner zone of basalts with a shallow inland dip. The major fracture zone has an overall trend of about $040^{\circ}$ while a number of apparently smaller faults have a more easterly trend.

The movement of the major fault down-throwing the Kap Dalton graben area was shown by Wager (1935) to exceed $600 \mathrm{~m}$. However, to the north-east of Kap Dalton marker horizons within the basalt sequence on both sides of the fault zone indicate that the vertical movement along this part of the major fault and crush zone is relatively minor. Extensive step faulting adjacent to the fault zone is associated with the tilting of the lavas in the outer zone.

\section{Dykes}

The majority of the dykes in the area have an average trend of about $070^{\circ}$ and may well be associated with the subsidiary faulting in this direction. The majority of the dykes were intruded prior to the major faulting down-throwing the Kap Dalton graben as they were here seen to be cut by the fault at an angle of $20-30^{\circ}$.

In hand samples the dykes appear to be of the same lava type as the surrounding flows.

\section{The basalts}

The basalts throughout the sequence investigated appear to be tholeiitic.

The lava succession of the Kap Dalton graben does not exceed $300 \mathrm{~m}$ and consists of relatively thin, sparsely porphyritic flows interspersed with horizons of volcanogenic sediment, shale and occasional pillow lava. In spite of good exposure no dykes were seen to cut this sequence. All this seems to indicate waning volcanic activity and to confirm Wager's theory that these lavas represent the top of the volcanic pile $(1935$, p. 13).

The lavas between Kap Dalton and Manby Halvø were traversed in several places covering the succession from sea level to $1100 \mathrm{~m}$. The total thickness of these lavas amounts to $1200-1300 \mathrm{~m}$, consisting of a $500-600 \mathrm{~m}$ lower sparsely porphyritic group and an upper mainly porphyritic sequence of $600-700 \mathrm{~m}$ with some very characteristic flows containing feldspar laths in well-defined aggregates up to $5 \mathrm{~cm}$ in diameter. Within this group an approx. $200 \mathrm{~m}$ thick horizon of thin, grey flows or flow units forms a characteristic marker horizon.

A varied, but generally verry porphyritic sequence on Steward $\emptyset, 500 \mathrm{~m}$ thick, cannot be matched with any part of the known succession. A number of flows within this sequence are characterised by the presence of a larger number of pyroxene phenocrysts associated with large feldspar aggregates and horizons of micro-pegmatite.

Near the base of this sequence $30-40 \mathrm{~m}$ of volcanogenic sediment and conglomerate occurs.

\section{Amygdale minerals}

The variation in amygdale minerals is small. Chalcedony-quartz was found throughout frequently associated with mesolite-scolecite and calcite, rarely stilbite and heulandite. Of 
other minerals laumontite occurs at the warm springs on Henry Land (Bøggild, 1905). No minerals belonging to the higher parts of Walker's zeolite zones (Walker, 1960) were seen in the area, including the supposed top of the entire succession below the sediments at Kap Dalton.

\section{Warm springs}

A warm spring was discovered at the head of Deichmann Fjord appearing as seeps surrounded by lush vegetation. The maximum emergence temperature of the water is about $35^{\circ} \mathrm{C}$. The area is extremely poorly exposed.

The warm springs on outer Henry Land mentioned by Nordenskjöld (1907) are well exposed near sea level and emerge from an alteration zone connected with a fault. A similar setting is suspected for the spring at Deichmann Fjord where a major fault has been projected across the narrowest part of Manby Halvø (Watt et al., 1972).

\section{References}

Bøggild, O. B. 1905: The minerals from the basalt of East-Greenland. Meddr Grønland 28, 97-129. Nordenskjöld, O. 1907: On the geology and physical geography of East-Greenland. Meddr Grønland 28, 151-284.

Wager, L. R. 1935: Geological investigations in East Greenland. Part II: Geology of Kap Dalton. Meddr Grønland 105,3, 32 pp.

Walker, G. P. L. 1960: Zeolite zones and dike distribution in relation to the structure of the basalts of eastern Iceland. J. Geol. 68, 515-528.

Watt, M. 1975: Photo-reconnaissance of the Blosseville Kyst between Steward Ø and Søkongens Bugt, central East Greenland. Rapp. Grønlands geol. Unders. 75, 91-95.

Watt, W. S., Emeleus, C. H. \& Watt, M. 1972: Preliminary report on the basalts of Volquart Boons Kyst, East Greenland. Rapp. Gronlands geol. Unders. 48, 75-83.

N.J.S.

Department of Geology, The University of Sheffield,

Mappin Street,

St. George's Square, Sheffield SI 3JD,

$U$ U. $K$. 